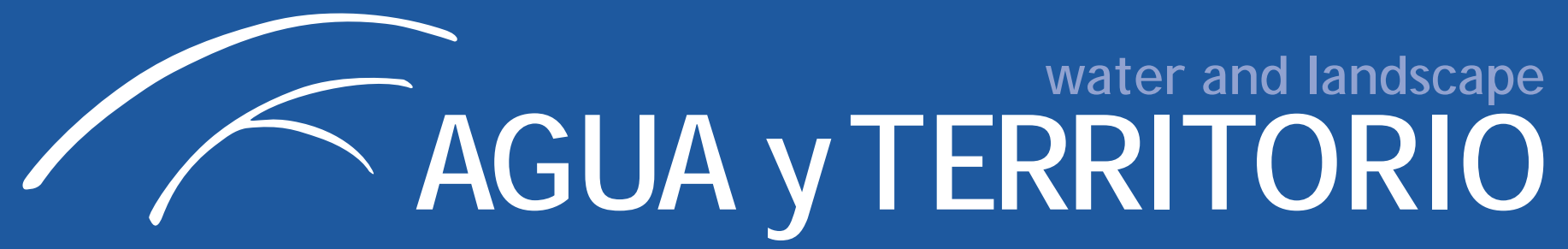

\title{
Mãe-d'água: Um contributo sobre o património hidráulico e abastecimento público de Guimarães (noroeste de Portugal)
}

\author{
Mãe-d'água: Una contribución sobre el patrimonio hidráulico \\ y el abastecimiento público de Guimarães (noroeste de Portugal) \\ Mãe-d'água: A Contribution to the Hydraulic Heritage \\ and Water Supply of Guimarães (Northwest Portugal) \\ Francisco da Silva Costa \\ Universidade do Minho, Guimarães, Portugal. costafs@geografia.uminho.pt
}

\begin{abstract}
Resumo - Guimarães foi classificado pela UNESCO como Património da Humanidade em 2001, tendo sido fundamental para tal, o riquíssimo património ligado à água. Com origens que remontam à Idade Média, o abastecimento de água à cidade de Guimarães demonstra um enorme conjunto de estruturas e infraestruturas hidráulicas de enorme interesse patrimonial. Pretende-se com esta artigo dar um contributo sobre o património hidráulico que resultou da relação entre 0 abastecimento público de água e a sociedade local e as potencialidades que decorreram da sua integração territorial na cidade de Guimarães.

Resumen - Guimarães fue declarado por la UNESCO como Património da Humanidad en 2001. Para esta declaración fue fundamental el riquisimo patrimonio ligado al agua. Sus orígenes se remontan a la Edad Media. El abastecimiento de agua a la ciudad de Guimarães consta de un enorme conjunto de estructuras e infraestructuras hidráulicas de un extraordinario interés patrimonial. El objetivo de este artículo es dar a conocer el patrimonio hidráulico que resultó de la relación entre la provisión pública del agua y la sociedad local, y las potencialidades generadas de su integración territorial en la ciudad de Guimarães.

Abstract - In 2001 UNESCO classified Guimarães as a World Heritage Site, and water was instrumental to such a rich heritage. With origins dating back to the Middle Ages, the water supply system of the city of Guimarães reveals a vast number of structures and hydraulic infrastructural assets of enormous cultural and historical interest. The objective of this article is to highlight the important role played by these assets, especially in forging a link between the public water supply and the local society, and eventually in promoting the territorial integration of the city of Guimarães.
\end{abstract}

\begin{abstract}
Palavras-chave: Guimarães, abastecimento público de água, património cultural, minas da Penha, estruturas hidráulicas Palabras clave: Guimarães, abastecimento público de agua, patrimonio cultural, minas de Penha, estructuras hidráulicas Keywords: Guimarães, water supply, historical-cultural heritage, mines of Penha, hydraulic structures
\end{abstract}

Información Artículo: Recibido: 13 noviembre 2013

Revisado: 10 abril 2014

Aceptado: 19 abril 2014

Códigos J EL: L95, N73, N93, Q25.

(c) Universidad de J aén / Seminario Permanente Agua, Territorio y Medio Ambiente (CSIC) 